patients who talk about CSA by relatives and family friends, and it certainly leads to a misdirection of preventive efforts. In a field so characterised by media distortion, it is important not to add to the misinformation which abounds.

Miltion, M. R. \& Mazey, G. C. (1996) Victims and perpetrators of child sexual abuse. British journal of Psychiotry, 169 408-415.

Romans, S. E., Martin, J. L., Andarson, J. C., et ol (1996) The 'anatomy' of female child sexual abuse: who does what to young girls? Australion and New Zealand journal of Psychiotry. 30. 319-325.

Wyatt, G. E. (1905) The sexual abuse of Afro-American and White-American women in childhood. Child Abuse and Neglect, 9, 507-519.

S. E. Romans Royal Free Hospital School of Medicine, University of London, Department of Psychiatry, Pond Street, London NW3 2PF

J. L. Martin Dunedin Clinical School, Otago Medical School, University of Otago, PO Box 913, Dunedin, New Zealand

\section{Urine screening for drugs}

Sir: We read with interest the letter by Craig (1996) concerning spurious amphetamine test results in the presence of trazodone. In the National Drug Treatment Centre Board, Ireland, we also routinely screen for amphetamines using EMIT-based Syva assays and have recorded false positives. These false results occur both in the presence of phenothiazines, specifically thioridazine and chlorpromazine, and also with trimipramine.

We have also had difficulty with Syva EMIT benzodiazepine tests with false negative results in the presence of short-acting benzodiazepines such as flunitrazepam. Using the Syva assay up to $10 \%$ of samples in this clinic were recorded as negative for benzodiazapine, which on retesting with a more sensitive technique were detected as positive for benzodiazepine.

The patient group served by the clinic, the majority of whom are opiate addicts, show increasing abuse of substances which they are aware are proving difficult to detect in urine tests. Thus the importance of clinical assessment in cases where amphetamine or flunitrazepam abuse is suspected cannot be underestimated. While urine screening has a role in the treatment of an opiate-addicted population, it must be accepted that current assays are not without limitations.

We would concur with Dr Craig that where possible confirmatory testing is advisable when using the amphetamine test; however, the most reliable test for confirmation is high-pressure liquid chromatography (Robertson \& Drummer, 1995), which is not universally available in the clinical setting.

Craig, R. J. (1996) Urine screening for drugs and trazodone (letter). British Journal of Psychiatry, 169, 669-670.

Robertson, M. D. \& Drummer, O. H. (1995) High-performance liquid chromatographic procedure for the measurement of nitrobenzodiazepines and their 7-amino metabolites in blood. Journal of Chromotography B: Biomedical Applications, 667. $179-184$.

R. Browne, D. Sloan, S. Fahy, D. Talbot, J. O'Connor National Drug Treatment Centre, Trinity Court, 31-32 Pearse Street, Dublin 2, Ireland

\section{Acute clozapine overdosage}

Sir: We have observed survival to a highdose intentional ingestion of clozapine in a young woman. The mortality rate in acute clozapine overdosage is approximately $12 \%$ according to the prescribing information provided by the manufacturer, Sandoz. Fatal cases are mostly associated with cardiac insufficiency and aspiration pneumonia and occur with dosages higher than $2 \mathrm{~g}$ (Le Blaye et al, 1992; Worm et al, 1993; Ines et al, 1994).

A 34-year-old woman with schizoaffective disorder, depressive type (DSM-IV) intentionally ingested $6-8 \mathrm{~g}$ clozapine after nearly three months of clozapine monotherapy (daily dose range $300-400 \mathrm{mg}$ ). At admission to the emergency ward one hour later, she presented in a deep coma, with mydriasis, plantar reflexes in flexion and no apparent focal neurological lesions. Blood pressure, heart rate, laboratory data, blood cell counts, ECG and chest X-ray were normal. She was lavaged and standard resuscitation therapeutic procedures were executed; cardiocirculatory and respiratory parameters as well as diuresis were monitored. At 14, 18 and 26 hours from ingestion plasma levels of clozapine and desmethylclozapine were, respectively, 5.7, 3.7 and $2.8 \mathrm{mg} / \mathrm{ml}$ and $1.55,1.2$ and $1.06 \mathrm{mg} / \mathrm{ml}$. On the sixth day sudden hypotension with abundant haematemesis appeared, continuing for two days in spite of treatment with somatostatin. The gastroscopic examination showed an erosive haemorrhagic gastritis located in the antrum. After 13 days she was discharged in a good physical condition.
Le Blaye et al (1992) reported 150 cases of clozapine overdose; the most frequent symptoms were impaired vigilance (from somnolence to coma) and tachycardia. Major complications were aspiration pneumonia and electrocardiographic changes (but severe arrhythmia rarely occurred). Although cases have been reported of full recovery after ingestion of high doses (Le Blaye et al, 1992) and very high plasma levels (>9000 ng/ml) (Ines et al, 1994), it has been considered that a dose of $400 \mathrm{mg}$ in a patient not previously treated may be life-threatening and that an overdose of $300 \mathrm{mg}$ in a previously treated patient may result in coma (La Blaye et al, 1992). The present case is quite typical in phenomenology: the patient developed a state of deep coma; there were no ECG changes nor cardiac complications. The occurrence after one week of an erosive haemorrhagic gastritis was interpreted as a non-specific, stress-related phenomenon, although it cannot be ruled out that this was in connection with the clozapine overdosage.

The acute toxicity profile of clozapine is similar to that of other neuroleptics, except for extrapyramidal symptoms (Le Blaye et $a l, 1992)$. There are reports of clozapineinduced delirium reversed with physostigmine (Schuster et al, 1977); the present case, however, did not show severe central or peripheral anticholinergic symptoms. It appears, in accordance with the literature (Le Blaye et al, 1992), that early treatment of overdose complications is successful under a standard approach, making the case for clozapine as a relatively safe drug.

Ines, S., Mahal, A., Hoss, J., et al (1994) Intoxication with clozapine: plasma levets above $9000 \mathrm{ng} / \mathrm{ml}$. Typical clinical picture - diagnostic confusion. Neuropsychopharmacology, 10 (suppl. 2), 122S.

Lo Bloye, 1., Donatini, B., Hall, M., ot ol (1992) Acute overdosage with clozapine: a review of the available clinical experience. Phormoceutical Medicine, 6, 169-178.

Schuster, P., Gabrid, E., Kuefferle, B., of of (1977) Reversal by physostigmine of clozapine-induced delirium. Clinical Toxicology. 10, 437-441.

Worm, K., Kringsholm, B., Steontoft, A., et al (1993) Clozapine cases with fatal, toxic or therapeutic concentrations. Internotional journal of Legal Medicine, 106, 115-118.

G. Piccini, P. Ceroni, C. Marchesi, C. Maggini Institute of Psychiatry, University of Parma, Piazzale Matteotti, 43100 Parma, Italy

G. Maestri Psychiatric Department, Piacenza General Hospital, Italy 